\title{
Physical activity and transcutaneous oxygen pressure in men with spinal cord injury
}

\author{
Beatriz Crespo-Ruiz, MSc; ${ }^{*}$ Antonio J. del-Ama, MScEng; ${ }^{1}$ Fernando J. Jiménez-Díaz, MD, PhD; ${ }^{2}$ Jennifer \\ Morgan, MA; ${ }^{3}$ Ana de la Peña-González, OT; ${ }^{1}$ Ángel M. Gil-Agudo, MD, PhD $^{\mathbf{1}}$ \\ ${ }^{1}$ Biomechanical and Technical Aids, Department of Spinal Cord Injury, National Hospital, Toledo, Spain; ${ }^{2}$ Laboratory \\ of Performance and Sports Rehabilitation, Faculty of Sport Science, University of Castilla La Mancha, Toledo, Spain; \\ ${ }^{3}$ Exercise and Sports Science Department, College of Public Health and Human Sciences, Oregon State University, \\ Corvallis, OR
}

\begin{abstract}
This pilot study proposed a method for assessing the status of vascular flow measured by transcutaneous oxygen pressure (TcPO2) in the area of the ischium in people with spinal cord injury (SCI). In a sample of 38 men (two groups: 12 physically active and 26 sedentary) with thoracic SCI, the distribution of the physiological response of the tissues under load during sitting was assessed through analysis of ischium TcPO2 values obtained by an oximeter. TcPO2 baseline, recovery time of TcPO2 after sitting (Trec), the percentage of TcPO2 (\%TcPO2) of maximum pressure TcPO2, and mechanic maximal pressure (Pmax) were evaluated. Trec in the physically active group was significantly lower $(p<0.05)$ than in the sedentary group. Likewise, significant differences in \%TcPO2 between groups $(p<0.05)$ were also found. We concluded that the physiological response of the tissues under an individual with SCI's own weight resulting from prolonged sitting is better in those who are physically active.
\end{abstract}

Key words: physical activity, physiological analysis, pressure mapping, pressure ulcers, rehabilitation, spinal cord injury, tissue loading, transcutaneous oxygen pressure, vascular flow, wheelchair cushions.

\section{INTRODUCTION}

Spinal cord injury (SCI) involves a number of changes at the metabolic and physiological levels that can be summarized as "alterations in cardiorespiratory system performance, decreased oxygen-carrying capacity, altered vasomotor regulation system with poor venous return, a reduction in muscle strength and endurance, decreased ability to maintain an adequate physiological response to exercise, blood stagnation in paralyzed limbs, a reduction in preload and cardiac output, vascular deficiency level, reduced blood volume and decrease in heart size" [1].

One of the most common complications in people with SCI is pressure ulcers (PUs). A PU is an area of localized cell necrosis resulting from mechanical disturbance in vascular and lymphatic skin and deeper tissues located between the skeletal plane and a tough outer surface.

\footnotetext{
Abbreviations: ACSM $=$ American College of Sports Medicine, $\mathrm{BMI}=$ body mass index, $\mathrm{ES}=$ electrostimulation, $\mathrm{IT}=$ ischial tuberosities, Pmax $=$ maximum mechanical stress, $\mathrm{PO} 2=$ oxygen pressure, $\mathrm{PU}=$ pressure ulcer, $\mathrm{SARS}=$ sacral anterior root stimulator, $\mathrm{SCI}=$ spinal cord injury, $\mathrm{T}=$ thoracic, $\mathrm{TcPO} 2=$ transcutaneous oxygen pressure, $\mathrm{TcPO} 2$ baseline $=$ transcutaneous oxygen pressure baseline values, $\mathrm{TcPO} 2 \mathrm{Trec}=$ recovery of baseline mmHg after relief.

*Address all correspondence to Beatriz Crespo-Ruiz, PhD; Unidad de Biomecánica y Ayudas Técnicas, Hospital Nacional de Parapléjicos de Toledo, Finca la Peraleda s/n, 45071 Toledo, Spain; +34925247763; fax: +34925247745.

Email: bcrespor@sescam.jccm.es

http://dx.doi.org/10.1682/JRRD.2011.05.0087
} 
Pressure on these areas cause compression and shear forces to the underlying structures. When the intensity and/ or time of application of these forces exceed a certain critical level, tissue damage occurs. The curve expressing the relationship between pressure and time is described by a parabola, so that the skin injury takes place under either low pressure for long periods of time or high pressure for short periods of time [2-3].

The risk of a PU is higher in groups such as the elderly and people with SCI [4]. The reported prevalence of PUs in patients with SCI who have already passed the initial phase of hospitalization is about 33 percent [5-6]. PUs could be one of the leading causes of death in this population if not treated properly. Although many factors are involved in the development of a PU [7-8], the findings of several experimental studies support the hypothesis that pressure at the interface between the user and the seating surface is the main factor involved in the emergence of a PU [9]. This pressure causes the reduction or even elimination of peripheral arterial blood circulation, thus causing the PU. Therefore, one of the most important tools for PU prevention is a sitting surface that relieves the pressure, for example, a wheelchair ulcer-preventing cushion. A combination of this specialized cushion for pressure reduction and pressurerelief movements, in which the wheelchair user performs "push-ups" or "forward leans," is considered the best option for PU prevention in people with SCI [10-13]. However, pressure-relief movements require good upper-limb strength and continued motivation, which are not always present in people with high-level lesions [14]. The incidence of PUs remains unacceptably high [15-18].

For the individual characterization of the mechanical pressure of the wheelchair cushion, the measure of the interface pressure between the person and the seating surface is the most common test performed in clinical settings [14,19-20]. However, the mechanical properties are not the only characterizations that indicate the risk of tissue damage. Note that not only the absolute values of pressure can vary from person to person, but also the variations in tissue composition of the high-risk areas can determine how soft tissues change in order to bear certain pressures [21]. In that sense, the cushion's mechanical behavior does not have much significance as a single determination of threshold value to determine the risk of tissue injury.

Studies in patients with SCI showed the following alterations in skin perfusion: the skin oxygenation uncompressed zone is lower in patients with SCI than in people without SCI [22-23]; the resistance of the microcirculation to external pressure, defined as the pressure caused by the closure of the capillaries, is impaired in patients with SCI [24]; the vasomotor response to a direct or alternating pressure and reactive hyperemia are impaired in people with SCI and predispose them to ischemia of the skin [25]; and finally, venous compliance is lower in people with SCI than in people without SCI [26].

In individuals with SCI, paralyzed muscles below the injury reduce the volume of the entire muscle used during exercise, and therefore, the capacities of the body are diminished [27]. As mentioned before, SCI also leads to significant morphological changes in metabolic and contractile properties of skeletal muscles below the lesion [28]. The physical work capacity in the SCI patient is generally impaired because of a sedentary lifestyle [29]. These conditions, a priori, may facilitate the development of PUs.

Typically, PU prevention has been studied in the rehabilitation hospital setting. The application of electrostimulation (ES) training to relieve the ischial pressure zone in sitting [10,30-32], functional magnetic electrostimulation, and ES of the sacral nerve root (sacral anterior root stimulator [SARS]) $[14,19]$ have been used to improve the behavior of vascular flow in relationship to clinical variables.

Physical activity now plays an important role on both social and personal levels in improving the quality of life of people with SCI [33], which includes prevention of PUs. A wide variety of studies provides evidence of improved quality of life for people with SCI related to physiological adaptation to exercise, both in additional rehabilitation [3440] and high-level sport settings [41-47], as well as the relationship of these adaptations to improving certain skills with the wheelchair [48-52].

According to previous reports, the ability of people with SCI to work is limited by the functional loss of muscle mass and sympathetic control [24]. Below the level of injury, vasoconstrictor function is lost [53]. Blood flows to inactive areas and is not effectively redistributed to those areas where metabolic demand is higher. Oxygen supply decreases to these areas when adaptations to exercise or any training program are required. Therefore, maintaining adequate oxygen pressure (PO2) is harder in those areas below the lesion, such as the ischial tuberosities (IT), which increases the risk of PU and warrants a multimodal assessment establishing the functional characteristics of wheelchair cushions. The consequences of mechanical pressure on vascular flow at the areas of risk 
should be added to the interface pressure between the person and the seating surface [20].

Recently, implanted muscular functional ES of gluteal muscles [54] and SARS implants in the suprasacral area $[14,19]$ have been shown to benefit seat pressure and tissue oxygenation. Therefore, recent studies have focused on evaluating the different effects of wheelchair tilt-in-space and recline angle on skin perfusion over the IT in wheelchair users with SCI by using laser doppler flowmetry [55]. Jan et al. explained that to further understand the efficacy of wheelchair tilt-in-space and recline for decreasing PU risk, systemic research of the efficacy of various angles of wheelchair tilt-in-space and recline on decreasing skin and muscle perfusion ischemia is needed [55]. A transient increase in skin blood flow after ischemia is regulated by a protective mechanism called reactive hyperemia [4850,56-57]. Reactive hyperemia is mediated mainly by local blood flow control mechanisms [51-52] Thus, people with SCI still show a reactive hyperemic response after blood occlusion [24]. Both the magnitude and duration of reactive hyperemia have been related to the magnitude and duration of the external loads [50]. With total relief occlusion, peak blood flow of hyperemic response may reach more than 10 -fold baseline blood flow. However, with partial pressure reduction, peak blood flow of a reactive hyperemic response is smaller [56].

Another alternative for the tissue viability assessment proposed is the measurement of transcutaneous PO2 (TcPO2) [58]. The principal advantage of this method is that it provides a noninvasive, real-time measurement of skin perfusion. However, its principal limitations are that the electrodes required are typically too rigid to be placed under the IT, particularly for people with SCI, and that it can be inaccurate when the oxygen level is low.

In this pilot study, we hypothesized that people with SCI who practiced regular physical activity would have better readaptation of vascular flow in the ischial area, where the risk of a PU is higher, after a period of prolonged pressure than people with SCI who did not engage in any physical activity. Our main objectives were to study TcPO2 as a method for evaluating the performance of SCI tissue viability in the ischial area and compare the behavior of vascular flow response measured by the level of TcPO2 at the ischial area in physically active and sedentary persons with SCI.

\section{METHODS}

\section{Participants}

In this pilot study, all regulations set by the corporate governance for the ethical use of human volunteers were followed. Participants were divided into two groups according to their level of physical activity: sedentary $(n=26)$ and physically active $(n=12)$. Informed consent was obtained for a total of 38 male participants with complete SCI. The sample's demographic and clinical-functional scale data are shown in Table 1. Braden Scale scores [59] and body mass index (BMI) are also included in Table 1. All participants used a manual wheelchair for mobility.

\section{Inclusion Criteria}

Inclusion criteria for both groups were men aged 18 to 55 yr who had complete thoracic (T)-type SCI (T1T12), as defined by the American Spinal Injury Association scale [60], for at least 6 mo. Additionally, participants had no occurrence of PUs, used a device seat cushion, and used their manual wheelchair for at least $6 \mathrm{~h}$ a day.

The physically active group participants were defined according to Ross and Jackson's criteria [61]. The individuals had a physical activity level characterized by regular training 2-3 times a week for between $45 \mathrm{~min}$ and $3 \mathrm{~h}$ [61]. These characteristics are in accordance with the latest American College of Sports Medicine (ACSM) recommendations for physical activity, which include people with disabilities [62]. The physically active group also had to use their wheelchair as a complement to physical activities so that we could somehow standardize the type of physical activity performed and the muscles most frequently involved.

Table 1.

Demographic and clinical-functional data of sample.

\begin{tabular}{lccccc}
\hline \multicolumn{1}{c}{ Group } & Age & BMI & $\begin{array}{c}\text { Lesion Evolution } \\
(\mathbf{m o})\end{array}$ & $\begin{array}{c}\text { Continuous } \\
\text { Sedestation (h) }\end{array}$ & $\begin{array}{c}\text { Braden Scale } \\
\text { Score }\end{array}$ \\
\hline Sedentary $(n=26)$ & $34.1 \pm 10.2$ & $23.4 \pm 2.7$ & $34.7 \pm 40.3$ & $6.9 \pm 2.9$ & $16.6 \pm 5.2$ \\
Physically Active $(n=12)$ & $26.7 \pm 5.6$ & $20.1 \pm 1.8$ & $62.7 \pm 48.0$ & $9.3 \pm 3.5$ & $16.1 \pm 5.3$ \\
\hline $\begin{array}{l}\text { Note: Group descriptive statistics (mean } \pm \text { standard deviation). } \\
\text { BMI = body mass index. }\end{array}$ & & & & \\
\hline \hline
\end{tabular}


We excluded any subject who had an illness or injury that prevented him from completing the tests, diabetes mellitus or peripheral vascular disease, hyperthermia or hypothermia in the last $48 \mathrm{~h}$, and a history of trauma in the past 4 weeks.

\section{Instrumentation}

The measurement was performed using a TcPO2 Radiometer Oximeter ${ }^{\circledR}$ model TCM400 (Radiometer Medical ApS; Copenhagen, Denmark) (Figure 1). The sensor temperature setting was $37^{\circ} \mathrm{C}-45^{\circ} \mathrm{C}$ with possible increments of $0.5^{\circ} \mathrm{C}$. The range of measure of TcPO2 is $0-2,000 \mathrm{~mm}$ $\mathrm{Hg}$, and the sensor E5250 measuring principle was a transcutaneous Clark-type $\mathrm{O}_{2}$ electrode. The sensors were an $\mathrm{O}_{2}$ sensor cathode (25 m platinum) and an $\mathrm{O}_{2}$ anode (silver), $15 \mathrm{~mm}$ in diameter, with $30 \mathrm{~mm}$ diameter fixation rings. The electrolyte solution of the sensor membrane was 1.2-propanediol, potassium chloride, sodium hydrogen carbonate, and deionised water. For the calibration specifications, the calibration gas was 5.0 percent $\mathrm{CO}_{2}$ and 20.9 percent $\mathrm{O}_{2}$, balance $\mathrm{N}_{2}$ and the gas flow was $8 \pm$ $2 \mathrm{~mL} / \mathrm{min}$ with automatic shut-off after 5, 10, 15, 20, and $50 \mathrm{~min}$, as required. The range of the calculated regional perfusion index was $0-3$.

The electrodes were surrounded by handmade polyethylene foam pads to decrease high-pressure area development (Figure 2). To standardize the experimental conditions and decrease interface pressure between users and cushion, we provided a single standard model type of cushion for all participants. The cushion selected was an air Roho Enhancer model (The Roho Group; Belleville,

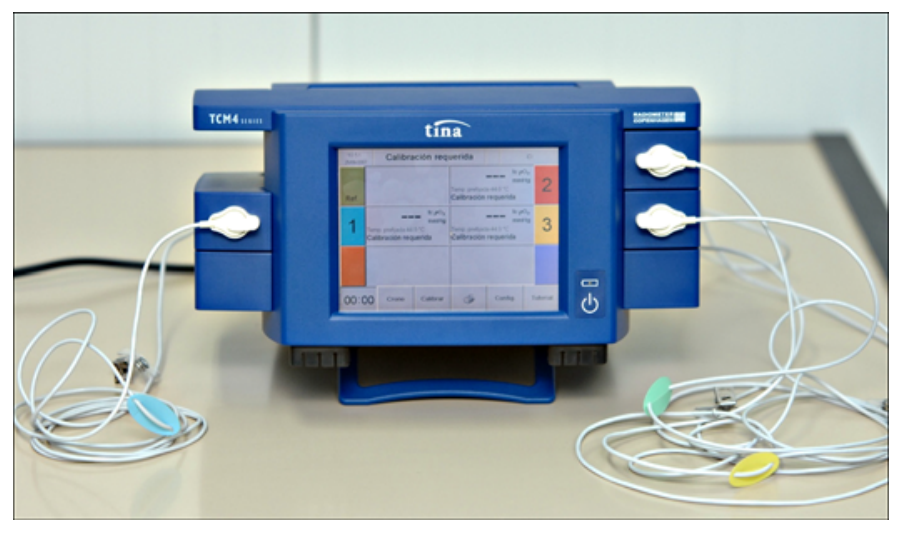

Figure 1.

System analysis of transcutaneous oxygen pressure with TCM400 monitor (Radiometer Medical ApS; Copenhagen, Denmark).
Illinois). The cushion had two compartments containing individually deformable pneumatic cells of three different heights $(6,8$, and $10 \mathrm{~cm})$ whose actions were adapted to each subject (Figure 3 ).

In order to regulate air pressure in the cushion, we used the information provided by the pressure sensor, Xsensor ${ }^{\circledR}$ model X2 (Xsensor Technology Corporation; Calgary, Alberta, Canada) (Figure 4). The pressure sensor registers the pressure distribution at the interface between the user and the cushion. The digital signal was derived from a computer via a high speed USB (Universal Serial Bus) port, which allowed for a sampling frequency of $10 \mathrm{~Hz}$ to display as the pressure was shown by the subject

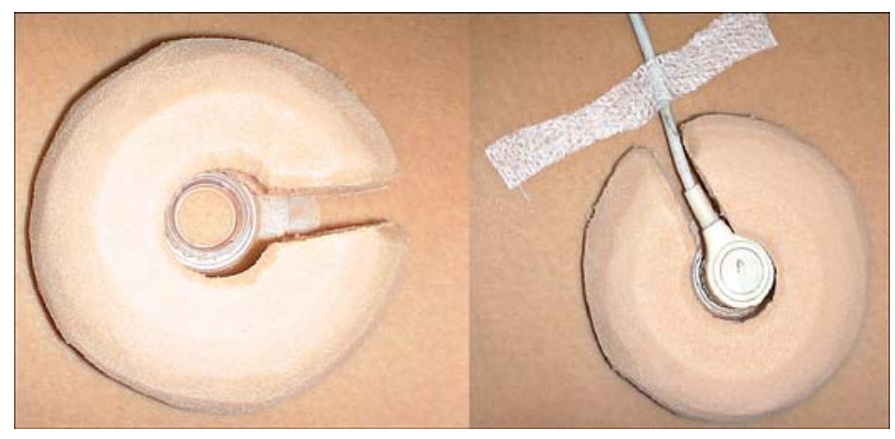

Figure 2.

Handmade polyethylene foam pads to decrease high-pressure area development.

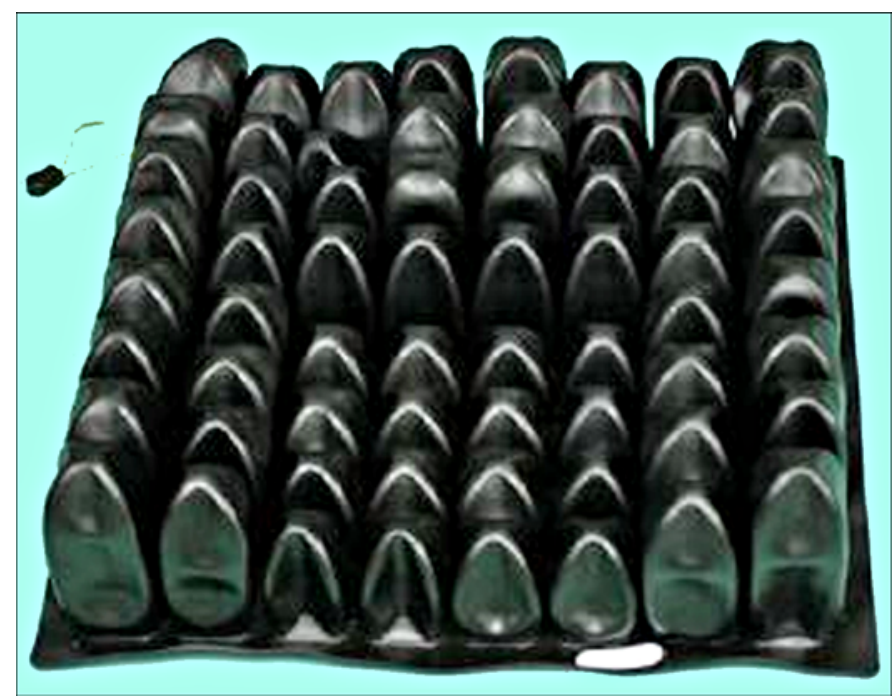

Figure 3.

Air Roho Enhancer model (The Roho Group; Belleville, Illinois). 
on the cushion; a pump adapted to cushion; and a pressure gauge model Digitron ${ }^{\circledR}$ model 2081P (Digitron Instrumentation Ltd; Wooland Road, Torquay, England) capable of measuring very small pressures (0-97 mm Hg). Realtime two-dimensional images of pressure distribution at the seat interface were produced with the graphical display software provided with the pressure mapping system and were saved on a personal computer.

\section{Procedure}

Informed consent and risk developing scales [59] were obtained from all participants. Following previous recommendations, we heated the testing room to $22^{\circ} \mathrm{C}$ [58]. Pressure distribution at the user-cushion interface was first measured in static pressure with the Xsensor 3p pad (Figure 5). Cushion inflation pressure was optimized for participants by regulating the inflation pressure of both chambers of the Xsensor 3p pad and following the protocol described previously [20]. Before the study began, the seat pressure mat was calibrated according to the manufacturer's instruction.

Physiological variable data were collected in the left buttock area (ischial left area). After oximeter calibration, the two electrodes were placed. One electrode was placed on the left buttock, and the other at a reference point in left second intercostal space.

Electrodes were placed as close as possible to the ischial area while participants were in a seated position.

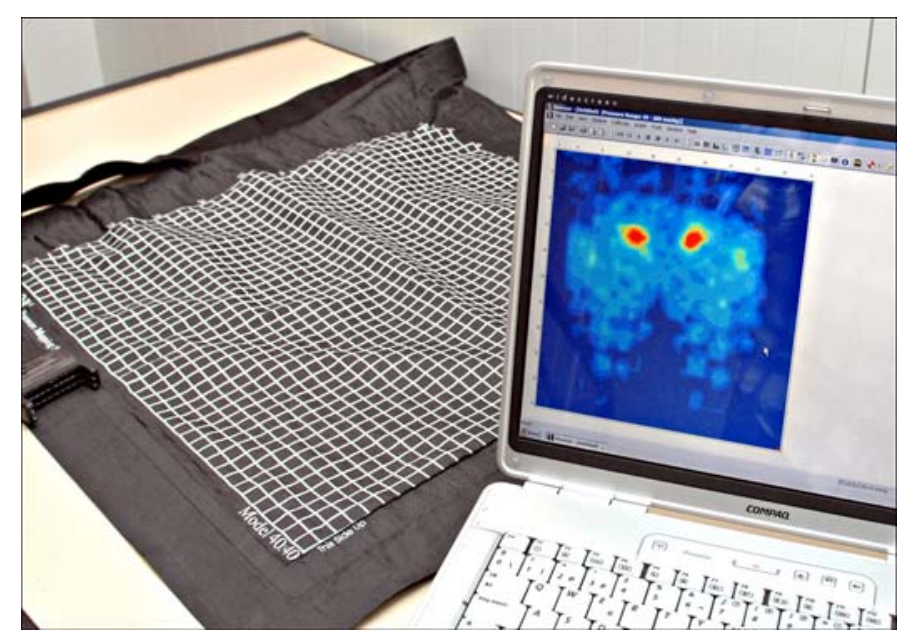

Figure 4.

Xsensor receptor system capacitive (Xsensor Technology Corporation; Calgary, Alberta, Canada) used in study to measure pressure distribution at participant-cushion interface.
To place electrodes, we positioned participants in right lateral decubitus with the hips flexed $90^{\circ}$, the knees bent between $70^{\circ}$ and $80^{\circ}$, and pelvic rotation avoided. The procedure was repeated on the left lateral decubitus. This yielded two brands (due to skin movement), between which, once the participant was prone, the electrode was placed [63].

After adjusting the correct placement of the electrodes, we proceeded to the placement of the sensor membranes (1.2-propanediol, potassium chloride, sodium hydrogen carbonate, and deionised water) and sprayed a drop of contact liquid (1.2-propanediol and deionised water) to ensure a suitable thermal conduction between skin and electrode. After location and placement of the oximeter sensor membranes, it was necessary to wait for 5 min to heat the electrode to $42^{\circ} \mathrm{C}$, allowing adequate vasodilatation contact area to take the initial steps for baseline data (millimeters of mercury) in the ischium, following manufacturer's instructions. In addition, the electrodes were covered with a polyethylene foam pad as previously mentioned to relieve the external pressure of contact with the surface.

To establish the data baseline at rest (millimeters of mercury), there was a 20 min waiting period, after which 90 percent of this value was calculated. Then, the participant was transferred to his wheelchair with the cushion individually optimized. In order to ensure pressure on the

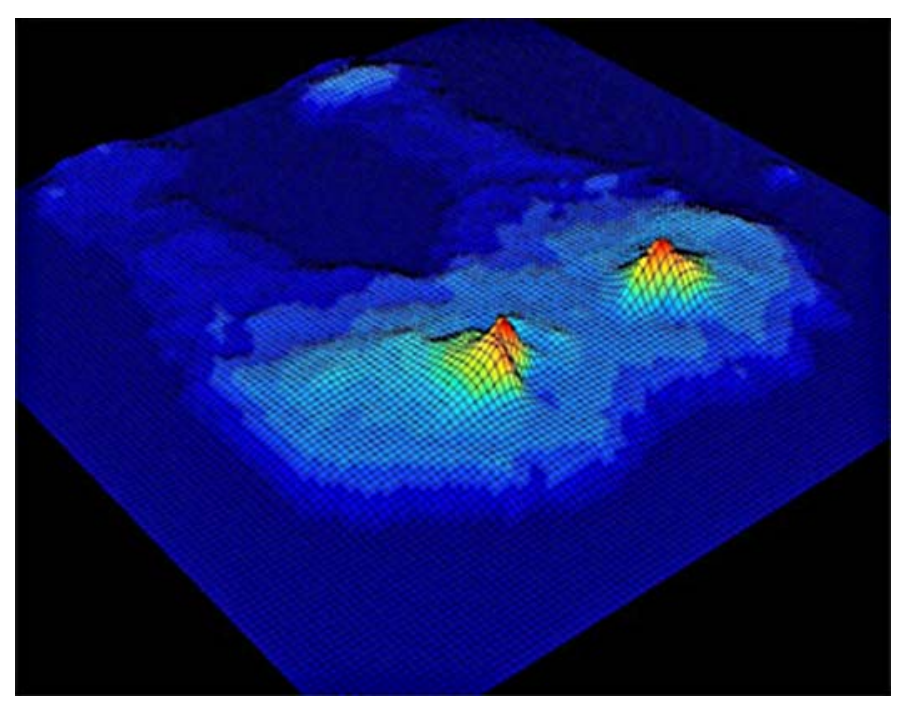

Figure 5.

Three-dimensional pressure distribution between user's buttock and cushion. Note highest values corresponding record registered with Xsensor (Xsensor Technology Corporation; Calgary, Alberta, Canada). 
ischial area similar to that which occurs in an everyday seated position, the participant remained in the position for $5 \mathrm{~min}$ and TcPO2 values were recorded and scored at the beginning and end of this period.

The participant was then transferred back to the bench and placed in the prone position until the recovery value of the ischium reached at least 90 percent of the previously calculated baseline or, alternatively, after $15 \mathrm{~min}$. It has been previously determined that after $20 \mathrm{~min}$, the reproducibility of the measure is decreased for data obtained in the supine sacrum [58].

\section{Data Analysis}

\section{Variables}

The peak value of maximum mechanical stress (Pmax) was analyzed to characterize the pressure distribution at the interface between the user and the cushion following data obtained with the Xsensor.

The variables registered from the physiological measures obtained with the oximeter (millimeters of mercury) were the TcPO2 baseline values (millimeters of mercury); the reduction of baseline support TcPO2 after sitting (millimeters of mercury); the percentage of value of that TcPO2 reduction from baseline (\%TcPO2); the recovery time (seconds), time elapsed from the occurrence of a support in a particular area, with the consequent decrease in TcPO2; and the recovery of baseline millimeters of mercury after this relief (TcPO2 Trec) (seconds).

\section{Statistical Analysis}

All data (Xsensor and Oximeter) were then converted to ASCII format. All statistical analysis was performed with SPSS, version 15 for Windows (IBM Corp.; Armonk, New York). The distributions of data and their descriptive statistics (mean and standard deviation) were obtained for each variable. Because of the sample size and characteristics, we conduncted a Kolmogorov-Smirnov test to verify the normal distribution of the sample. All variables presented a normal distribution, so a two-tailed nonpaired $t$-test was used with a 95 percent confidence interval to compare variables between groups. The significance level was set at $p<0.05$ for all statistical tests.

\section{RESULTS}

The TcPO2 baseline data were similar in both groups, as evidenced by no significant difference between them. Similarly, note that no significant differences existed between the two groups with respect to the resulting Pmax optimal mechanical characterization of the wheelchair cushion. No differences were found between groups in relation to the values obtained from the Braden scale (Table 2). Therefore, we can assume that the mechanical behavior of the cushion and tissue situation was similar in both groups.

TcPO2 reduction values (milligrams of mercury) were not significantly different between the two groups when unloading on the ischial area, such as moving from prone to seated (35.6 \pm 18.2 in the sedentary group vs $47.7 \pm 12.6$ in the physically active group, $p>0.05$ ). However, when we individually analyzed the percentage value, which represented the reduction in relation to baseline, differences were found: the data obtained from the physically active group were higher $(99.0 \% \pm 1.3 \%)$ than the data from the sedentary group $(71.5 \% \pm 34.6 \%)$ $(p<0.05)$ (Table 2). Regarding the value of TcPO2 Trec (seconds), the value obtained in the physically active participants was significantly lower than in the sedentary participants $(125.3 \pm-23.2 \mathrm{~s}$ vs $206.7 \pm 231.6 \mathrm{~s}$, respectively; $p<0.05$ ) (Table 2).

\section{DISCUSSION}

A methodology to study TcPO2 values and their use as a method for evaluating the performance of SCI tissue

Table 2.

Descriptive results of mechanical and physiological variables collected.

\begin{tabular}{|c|c|c|c|c|c|}
\hline Group & $\begin{array}{c}\text { TcPO2 Baseline } \\
\text { (mmHg) }\end{array}$ & $\begin{array}{l}\text { TcPO2 Reduction } \\
\text { (mmHg) }\end{array}$ & TcPO2 Trec (s) & \%ТсPO2 & Pmax (mmHg) \\
\hline Sedentary $(n=26)$ & $51.6 \pm 12.0$ & $35.6 \pm 18.2$ & $206.7 \pm 23.6$ & $71.5 \pm 34.6$ & $85.7 \pm 29.8$ \\
\hline Physically Active ( $n=12)$ & $47.2 \pm 10.0$ & $47.7 \pm 12.6$ & $125.3 \pm 23.2^{*}$ & $99.0 \pm 1.3^{*}$ & $87.7 \pm 23.2$ \\
\hline
\end{tabular}


viability in the area of the ischium was developed. Additionally, the initial hypothesis was confirmed. The tissue response in the readaptation of vascular flow in an area at risk for PUs after a period of prolonged pressure was better in the physically active group.

TcPO2 baseline values were similar in the two groups studied, indicating that without pressure, both groups had similar tissue vascularization in the ischial area. Both populations had similar risk of experiencing a PU in terms of Braden scale scores. BMI was lower in the physically active group versus the sedentary group, which is likely attributed to their meeting the ACSM recommendations for physical activity and their active life profiles.

In the absence of extensive literature describing ischial TcPO2 results comparable with those obtained in this study, we assumed that mechanical pressure higher than 13-32 mm Hg could produce a reduction in TcPO2 with consequent risk of PU in the zone [64]. In relation to this study, the average value of Pmax exerted and recorded in the area of the ischium in a sitting position was $85.7 \pm$ $29.8 \mathrm{~mm} \mathrm{Hg}$ in the sedentary group and $87.7 \pm 23.2 \mathrm{~mm}$ $\mathrm{Hg}$ in the physically active group. Thus, the IT-area pressure on the pad-user interface greatly exceeded recommended values $[20,64]$. In this situation, the excessive use of a wheelchair, but without any corresponding changes in posture, significantly increases the risk of PUs [63].

Moreover, analysis of the pressure distribution at the interface between user and cushion showed that, starting from a seated position in the same cushion, Pmax in both populations was similar. These results are consistent with a previous study from a larger population with SCI, which compared the pressure distribution between four different types of cushions using the Xsensor pressure sensor [20].

In relation to reducing TcPO2 (millimeters of mercury) in the ischium during sitting, measuring this variable in absolute values did not show any significant differences between groups. However, statistical differences were found when the reduction was calculated in percentages (\%TcPO2) relative to the baseline data recorded for each user, with the values being higher in the physically active group. This might be due to overuse of the wheelchair and lower BMI in the physically active group (remember that one of the criteria for inclusion was that the wheelchair was not only used as a common transport, but also as a complement for training). This may potentially expose the skin and soft tissue in the ischial area to longer periods of friction and thus a greater chance of skin injury [2].
Note that in people with complete SCI, functional capability is limited by the functional loss of muscle mass and sympathetic control below the level of injury. Oxygen transport through the blood circulation in those areas affected by the injury [22-23] is reduced and, therefore, also reduces the chances of maintaining good TcPO2 during external pressure on the IT, located below the sample's level of injury (T6-T12). The current clinical practice assumes that a decrease in seating pressure is associated with an increase in skin and muscle perfusion, thus decreasing the risk for PUs.

Regarding the analysis of TcPO2 Trec, we consider this variable as one of the most significant to note, because we are being informed of the vascular response's capacity to adapt to stimuli [63]. A significantly lower TcPO2 Trec $(p<0.05)$ in the group of physically active participants may indicate a better capacity for readaptation of vascular flow in the ischial area after pressure. Note that exposure to low pressure for a long time or high pressure for a short time increases the risk of skin lesions [2]. This would indicate, a priori, a benefit for the relief of pressure when, for example, performing push-ups or forward leans or transferring from the wheelchair to bed to relieve the area under pressure and recover the TcPO2 baseline in less time.

The practice of physical activity in people with SCI and paraplegia results in improved cardiorespiratory capacity, such as maximal aerobic power, peak oxygen consumption, forced expiratory flow, forced vital capacity, and improved muscle strength in the upper limbs [65]. This may exert a decisive influence on the capacity to transport oxygen in the areas most affected by disuse resulting from the SCI itself. Considering this point and the results shown in the study, practice of regular physical activity could contribute to better TcPO2 and, consequently, to better distribution of vascular flow, positively influencing tissue viability of the injured spinal vascular level. However, further studies are needed to confirm this finding.

On the other hand, if the injury affects the thoracic cord, sympathetic control of the splenic vascular area is affected, thus reducing the possibility of driving the blood to active areas and consequently increasing the risk of PU development. In addition, the control deficiency affects renal sympathetic activation of the renin-angiotensin system. Angiotensin II and III exert their action on blood vessel walls, increasing muscle tone and, in turn, cardiac contractility of the heart. So, both cardiovascular mechanisms are also affected by the SCI and may directly influence the redistribution of blood flow through the body. 
There are also common disorders in the metabolism of carbohydrates. The change resulting from the lesion would be evidenced by glucose tolerance alterations and increased insulin resistance; thus, the predisposition to diabetes mellitus type 2 would be increased in this population [66-67]. In turn, this disorder would also be related to the degree of neurological impairment experienced by people with SCI in both completeness (complete/incomplete) and level of injury (tetraplegic/paraplegic). They present with alterations in glucose tolerance [68] as a result of muscle atrophy [69-70] and alterations in the proportions of muscle fiber type (decreased type I resulting in decreased muscle oxidative capacity) [71-72]. This could decisively affect physiological oxygen perfusion and, thus, vascular flow in areas below the level of injury, such as the ITs.

During this study, two main elements were considered to avoid injuries to participants. One was the nature of the electrode, which is too rigid to be placed under the IT, particularly in an SCI population. Various adjustments were considered in the protocol that would prevent any problems arising from the external pressure caused by its rigidity. Manufactured pads that surrounded the electrodes and reduced time of exposure were used. The patients' skin condition was carefully assessed before and after each test for any sign of skin damage in any of the two areas where the electrodes were placed. Another problem was that the electrode needed to be heated to $43^{\circ} \mathrm{C}-45^{\circ} \mathrm{C}$ to achieve maximum vessel dilatation. The heated electrode itself can cause potential damages to the skin, but this condition has been reported in previous validated studies and no skin damage was found [71-72]. Following these two precautions, no skin problems were found during the procedure.

Considering the limitations of this study, we found a discrepancy in the regulation of temperature sensors. In our study, the value was lower $\left(42^{\circ} \mathrm{C}\right)$ than reported in previous studies with people with SCI $\left(44.5^{\circ} \mathrm{C}\right.$ [58] and $44^{\circ} \mathrm{C}$ [73]) or with people with amputations $\left(43^{\circ} \mathrm{C}\right.$ [73]), making it difficult to compare results; yet in this case, because of the risk of producing a PU as a result of overheating of the electrode, we followed the manufacturer's recommendations.

Another limitation found was that many variables $[7,74]$ may have an effect when one is considering the viability of tissue and blood flow distribution measured in TcPO2 (millimeters of mercury). Such factors can be sex, ratio of adipose tissue, smoking status, number of hours spent sitting, maintenance of proper hygiene, pre- ventive education carried out by all health specialists during the period of hospitalization, or blood pressure $[9,58]$. Further research in which these variables are, as far as possible, properly controlled for is warranted.

According to the results and taking into account the limitations of the study, we confirmed the initial hypothesis that the physically active participants would have better readaptation of vascular flow in the ischial area at risk of a PU after a prolonged pressure period when compared with the sedentary participants. However, the results cannot be considered definitive by the fact that it is only the realization of the physical activity variable that causes these lower values in the recovery time, because the onset of PUs involves many other determining factors [74]. Testing is recommended to consolidate this methodology to more strictly assess the demographic variables, as are controlled prospective studies that monitor the operation of a concrete program of adapted physical activity and assess its possible effect.

\section{CONCLUSIONS}

We present results from a preliminary pilot study in which we used TcPO2 values (millimeters of mercury) to assess the status of tissue viability in an ischial area at risk of PUs during sitting. The vascular response of the tissue area under pressure seemed to be better in a population with SCI who was regularly active than in a population with SCI who was sedentary. This first pilot study offers a very interesting line of research in the field of physical activity and sport for the improvement of the quality of life for people with SCI.

\section{ACKNOWLEDGMENTS}

\author{
Author Contributions: \\ Study concept and design: B. Crespo-Ruiz, Á. M. Gil-Agudo. \\ Study planning: B. Crespo-Ruiz. \\ Software development: A. J. del-Ama. \\ Acquisition of data: F. J. Jiménez-Díaz, A. J. del-Ama, \\ A. de la Peña-González. \\ Analysis of data: B. Crespo-Ruiz, Á. M. Gil-Agudo, \\ F. J. Jiménez-Díaz, A. J. del-Ama, A. de la Peña-González. \\ Interpretation of data: B. Crespo-Ruiz. \\ Drafting of manuscript: B. Crespo-Ruiz. \\ Completion of manuscript: B. Crespo-Ruiz, Á. M. Gil-Agudo. \\ Translation of manuscript: J. Morgan.
}


Financial Disclosures: The authors have declared that no competing interests exist.

Funding/Support: This material was unfunded a the time of manuscript preparation.

Additional Contributions: Since completion of this study, Beatriz Crespo-Ruiz has received her PhD.

Institutional Review: All regulations set by the corporate governance for the ethical use of human volunteers were followed. All participants provided informed consent.

Participant Follow-Up: The authors do not plan to inform participants of the publication of this study. However, participants have been encouraged to check the study Web site for updated publications.

Disclaimer: No commercial party having a direct financial interest in the results of the research supporting this article has or will confer a benefit upon the authors or upon any organization with which the authors are associated.

\section{REFERENCES}

1. Meyer PR. Health benefits derived by the paraplegic involved in sport or why sports are important in the life of the paraplegic. In: David F. Apple Jr, editor. Physical fitness: a guide for individuals with spinal cord injury. Darby (PA): Diane Publishing Co; 1999. p. X-XIII.

2. Patterson RP, Fisher SV. Sitting pressure-time patterns in patients with quadriplegia. Arch Phys Med Rehabil. 1986; 67(11):812-14. [PMID:3778177]

3. Kosiak M. A mechanical resting surface: its effect on pressure distribution. Arch Phys Med Rehabil. 1976;57(10): 481-84. [PMID:973791]

4. Salzberg CA, Byrne DW, Cayten CG, Kabir R, van Niewerburgh P, Viehbeck M, Long H, Jones EC. Predicting and preventing pressure ulcers in adults with paralysis. Adv Wound Care. 1998;11(5):237-46. [PMID:10326341]

5. Fuhrer MJ, Garber SL, Rintala DH, Clearman R, Hart KA. Pressure ulcers in community-resident persons with spinal cord injury: prevalence and risk factors. Arch Phys Med Rehabil. 1993;74(11):1172-77. [PMID:8239957]

6. Vidal J, Sarrias M. An analysis of the diverse factors concerned with the development of pressure sores in spinal cord injured patients. Paraplegia. 1991;29(4):261-67.

[PMID:1870891] http://dx.doi.org/10.1038/sc.1991.37

7. Krause JS, Vines CL, Farley TL, Sniezek J, Coker J. An exploratory study of pressure ulcers after spinal cord injury: relationship to protective behaviors and risk factors. Arch Phys Med Rehabil. 2001;82(1):107-13. [PMID:11239295] http://dx.doi.org/10.1053/apmr.2001.18050

8. Mawson AR, Biundo JJ Jr, Neville P, Linares HA, Winchester Y, Lopez A. Risk factors for early occurring pressure ulcers following spinal cord injury. Am J Phys Med
Rehabil. 1988;67(3):123-27. [PMID:3377890]

http://dx.doi.org/10.1097/00002060-198806000-00007

9. Ferrarin M, Andreoni G, Pedotti A. Comparative biomechanical evaluation of different wheelchair seat cushions. J Rehabil Res Dev. 2000;37(3):315-24.

[PMID:10917263]

10. Bogie KM, Nuseibeh I, Bader DL. Early progressive changes in tissue viability in the seated spinal cord injured subject. Paraplegia. 1995;33(3):141-47. [PMID:7784116] http://dx.doi.org/10.1038/sc.1995.31

11. Guttmann L. Spinal cord injuries: comprehensive management and research. 2nd ed. London (England): Blackwell Scientific; 1976.

12. Coggrave MJ, Rose LS. A specialist seating assessment clinic: changing pressure relief practice. Spinal Cord. 2003; 41(12):692-95. [PMID:14639449] http://dx.doi.org/10.1038/sj.sc.3101527

13. Ferguson-Pell MW, Wilkie IC, Reswick JB, Barbenel JC. Pressure sore prevention for the wheelchair-bound spinal injury patient. Paraplegia. 1980;18(1):42-51.

[PMID:7375126]

http://dx.doi.org/10.1038/sc.1980.7

14. Liu LQ, Nicholson GP, Knight SL, Chelvarajah R, Gall A, Middleton FR, Ferguson-Pell MW, Craggs MD. Interface pressure and cutaneous hemoglobin and oxygenation changes under ischial tuberosities during sacral nerve root stimulation in spinal cord injury. J Rehabil Res Dev. 2006; 43(4):553-64. [PMID:17123193] http://dx.doi.org/10.1682/JRRD.2005.08.0135

15. Niazi ZB, Salzberg CA, Byrne DW, Viehbeck M. Recurrence of initial pressure ulcer in persons with spinal cord injuries. Adv Wound Care. 1997;10(3):38-42.

[PMID:9306777]

16. Garber SL, Rintala DH. Pressure ulcers in veterans with spinal cord injury: a retrospective study. J Rehabil Res Dev. 2003;40(5):433-41. [PMID:15080228] http://dx.doi.org/10.1682/JRRD.2003.09.0433

17. Krause JS, Broderick L. Patterns of recurrent pressure ulcers after spinal cord injury: identification of risk and protective factors 5 or more years after onset. Arch Phys Med Rehabil. 2004;85(8):1257-64. [PMID:15295750] http://dx.doi.org/10.1016/j.apmr.2003.08.108

18. Yarkony GM, Heinemnn W. Pressure ulcers. In: Stover SL, Delisa JA, Whiteneck GC, editors. Spinal cord injury: clinical outcomes from the model systems. Gaithersburg (MD): Aspen Publishers; 1995. p. 100-119.

19. Liu LQ, Nicholson GP, Knight SL, Chelvarajah R, Gall A, Middleton FR, Ferguson-Pell MW, Craggs MD. Pressure changes under the ischial tuberosities of seated individuals during sacral nerve root stimulation. J Rehabil Res Dev. 2006;43(2):209-18. [PMID:16847787] http://dx.doi.org/10.1682/JRRD.2005.04.0078 
20. Gil-Agudo A, De la Peña-González A, Del Ama-Espinosa A, Pérez-Rizo E, Díaz-Domínguez E, Sánchez-Ramos A. Comparative study of pressure distribution at the usercushion interface with different cushions in a population with spinal cord injury. Clin Biomech (Bristol, Avon). 2009;24(7):558-63. [PMID:19447532]

http://dx.doi.org/10.1016/j.clinbiomech.2009.04.006

21. Makhsous M, Priebe M, Bankard J, Rowles D, Zeigler M, Chen D, Lin F. Measuring tissue perfusion during pressure relief maneuvers: insights into preventing pressure ulcers. J Spinal Cord Med. 2007;30(5):497-507. [PMID:18092567]

22. Liu MH, Grimm DR, Teodorescu V, Kronowitz SJ, Bauman WA. Transcutaneous oxygen tension in subjects with tetraplegia with and without pressure ulcers: a preliminary report. J Rehabil Res Dev. 1999;36(3):202-6. [PMID:10659803]

23. Mawson AR, Siddiqui FH, Connolly BJ, Sharp CJ, Summer WR, Biundo JJ Jr. Sacral transcutaneous oxygen tension levels in the spinal cord injured: risk factors for pressure ulcers? Arch Phys Med Rehabil. 1993;74(7):745-51. [PMID:8328898]

http://dx.doi.org/10.1016/0003-9993(93)90037-B

24. Schubert V, Fagrell B. Postocclusive reactive hyperemia and thermal response in the skin microcirculation of subjects with spinal cord injury. Scand J Rehabil Med. 1991; 23(1):33-40. [PMID:2035001]

25. Hagisawa S, Ferguson-Pell M, Cardi M, Miller SD. Assessment of skin blood content and oxygenation in spinal cord injured subjects during reactive hyperemia. J Rehabil Res Dev. 1994;31(1):1-14. [PMID:8035356]

26. Wecht JM, de Meersman RE, Weir JP, Bauman WA, Grimm DR. Effects of autonomic disruption and inactivity on venous vascular function. Am J Physiol Heart Circ Physiol. 2000;278(2):H515-20. [PMID:10666083]

27. Glaser RM, Foley DM, Laubach LL, Sawka MN, Suryaprasad AG. An exercise test to evaluate fitness for wheelchair activity. Paraplegia. 1979;16(4):341-49.

[PMID:431964]

http://dx.doi.org/10.1038/sc.1978.66

28. Hartkopp A, Harridge SD, Mizuno M, Ratkevicius A, Quistorff B, Kjaer M, Biering-Sörensen F. Effect of training on contractile and metabolic properties of wrist extensors in spinal cord-injured individuals. Muscle Nerve. 2003;27(1):72-80. [PMID:12508298]

http://dx.doi.org/10.1002/mus.10290

29. Dearwater SR, LaPorte RE, Robertson RJ, Brenes G, Adams LL, Becker D. Activity in the spinal cord-injured patient: an epidemiologic analysis of metabolic parameters. Med Sci Sports Exerc. 1986;18(5):541-44. [PMID:3534508]

30. Levine SP, Kett RL, Cederna PS, Bowers LD, Brooks SV. Electrical muscle stimulation for pressure variation at the seating interface. J Rehabil Res Dev. 1989;26(4):1-8. [PMID:2600864]

31. Levine SP, Kett RL, Gross MD, Wilson BA, Cederna PS, Juni JE. Blood flow in the gluteus maximus of seated individuals during electrical muscle stimulation. Arch Phys Med Rehabil. 1990;71(9):682-86. [PMID:2375675]

32. van Londen A, Herwegh M, van der Zee CH, Daffertshofer A, Smit CA, Niezen A, Janssen TW. The effect of surface electric stimulation of the gluteal muscles on the interface pressure in seated people with spinal cord injury. Arch Phys Med Rehabil. 2008;89(9):1724-32.

[PMID:18760157]

http://dx.doi.org/10.1016/j.apmr.2008.02.028

33. Anneken V, Hanssen-Doose A, Hirschfeld S, Scheuer T, Thietje R. Influence of physical exercise on quality of life in individuals with spinal cord injury. Spinal Cord. 2010; 48(5):393-99. [PMID:19841634] http://dx.doi.org/10.1038/sc.2009.137

34. de Groot S, de Bruin M, Noomen SP, van der Woude LH. Mechanical efficiency and propulsion technique after 7 weeks of low-intensity wheelchair training. Clin Biomech (Bristol, Avon). 2008;23(4):434-41. [PMID:18077065] http://dx.doi.org/10.1016/j.clinbiomech.2007.11.001

35. Janssen TW, van Oers CA, Veeger HE, Hollander AP, van der Woude LH, Rozendal RH. Relationship between physical strain during standardised ADL tasks and physical capacity in men with spinal cord injuries. Paraplegia. 1994; 32(12):844-59. [PMID:7708424] http://dx.doi.org/10.1038/sc.1994.131

36. Dallmeijer AJ, Hopman MT, Angenot EL, van der Woude LH. Effect of training on physical capacity and physical strain in persons with tetraplegia. Scand J Rehabil Med. 1997;29(3):181-86. [PMID:9271153]

37. Dallmeijer AJ, van der Woude LH, Veeger HE, Hollander AP. Effectiveness of force application in manual wheelchair propulsion in persons with spinal cord injuries. Am J Phys Med Rehabil. 1998;77(3):213-21. [PMID:9635556] http://dx.doi.org/10.1097/00002060-199805000-00006

38. Valent L, Dallmeijer A, Houdijk H, Talsma E, van der Woude LH. The effects of upper body exercise on the physical capacity of people with a spinal cord injury: a systematic review. Clin Rehabil. 2007;21(4):315-30.

[PMID:17613572] http://dx.doi.org/10.1177/0269215507073385

39. Dallmeijer AJ, Kilkens OJ, Post MW, de Groot S, Angenot EL, van Asbeck FW, Nene AV, van der Woude LH. Handrim wheelchair propulsion capacity during rehabilitation of persons with spinal cord injury. J Rehabil Res Dev. 2005; 42(3, Suppl 1):55-63. [PMID:16195963] http://dx.doi.org/10.1682/JRRD.2004.08.0081

40. Kilkens OJ, Dallmeijer AJ, Nene AV, Post MW, van der Woude LH. The longitudinal relation between physical 
capacity and wheelchair skill performance during inpatient rehabilitation of people with spinal cord injury. Arch Phys Med Rehabil. 2005;86(8):1575-81. [PMID:16084810] http://dx.doi.org/10.1016/j.apmr.2005.03.020

41. Crespo-Ruiz B, Gil-Agudo A, Del Ama-Espinosa A. Relation between kinematic analysis of wheelchair propulsion and wheelchair functional basketball classification. Adapt Phys Activ Q. 2011;28(2):157-72. [PMID:21757787]

42. Gil-Agudo A, Del Ama-Espinosa AJ, Crespo-Ruiz B. Wheelchair basketball quantification. Phys Med Rehabil Clin N Am. 2010; 21(1):141-56. [PMID: 19951783]

43. Goosey-Tolfrey V. Physiological profiles of elite wheelchair basketball players in preparation for the 2000 Paralympic Games. Adapt Phys Activ Q. 2005;22:57-66.

44. van der Woude LH, Bouten C, Veeger HE, Gwinn T. Aerobic work capacity in elite wheelchair athletes: a cross-sectional analysis. Am J Phys Med Rehabil. 2002;81(4):261-71. [PMID:11953543] http://dx.doi.org/10.1097/00002060-200204000-00004

45. van der Woude LH, Bakker WH, Elkhuizen JW, Veeger HE, Gwinn T. Anaerobic work capacity in elite wheelchair athletes. Am J Phys Med Rehabil. 1997;76(5):355-65. [PMID:9354488] http://dx.doi.org/10.1097/00002060-199709000-00002

46. Veeger HE, Hadj Yahmed M, van der Woude LH, Charpentier P. Peak oxygen uptake and maximal power output of Olympic wheelchair-dependent athletes. Med Sci Sports Exerc. 1991;23(10):1201-9. [PMID:1836828] http://dx.doi.org/10.1249/00005768-199110000-00015

47. van der Woude LH, Bakker WH, Elkhuizen JW, Veeger HE, Gwinn T. Propulsion technique and anaerobic work capacity in elite wheelchair athletes: cross-sectional analysis. Am J Phys Med Rehabil. 1998;77(3):222-34. [PMID:9635557] http://dx.doi.org/10.1097/00002060-199805000-00007

48. Lewis T, Grant R. Observations upon reactive hyperaemia in man. Heart. 1925;12:73-120.

49. Mayrovitz HN, Sims N, Taylor MC, Dribin L. Effects of support surface relief pressures on heel skin blood perfusion. Adv Skin Wound Care. 2003;16(3):141-45.

[PMID:12789036] http://dx.doi.org/10.1097/00129334-200305000-00012

50. Rendell MS, Wells JM. Ischemic and pressure-induced hyperemia: a comparison. Arch Phys Med Rehabil. 1998; 79(11):1451-55. [PMID:9821909] http://dx.doi.org/10.1016/S0003-9993(98)90243-X

51. Jan YK, Brienza D. Tissue mechanics and blood flow factors in pressure ulcers of people with spinal cord injury. In: Gefen A, editor. The pathomechanics of tissue injury and disease, and the mechanophysiology of healing. Kerala (India): Research Signpost; 2009. p. 241-59.
52. Engelke KA, Halliwill JR, Proctor DN, Dietz NM, Joyner MJ. Contribution of nitric oxide and prostaglandins to reactive hyperemia in human forearm. J Appl Physiol. 1996; 81(4):1807-14. [PMID:8904603]

53. Hopman MT. Circulatory responses during arm exercise in individuals with paraplegia. Int J Sports Med. 1994;15(3): 126-31. [PMID:8005724] http://dx.doi.org/10.1055/s-2007-1021033

54. Bogie KM, Triolo RJ. Effects of regular use of neuromuscular electrical stimulation on tissue health. J Rehabil Res Dev. 2003;40(6):469-75. [PMID:15077659] http://dx.doi.org/10.1682/JRRD.2003.11.0469

55. Jan YK, Jones MA, Rabadi MH, Foreman RD, Thiessen A. Effect of wheelchair tilt-in-space and recline angles on skin perfusion over the ischial tuberosity in people with spinal cord injury. Arch Phys Med Rehabil. 2010;91(11):1758-64. [PMID:21044723] http://dx.doi.org/10.1016/j.apmr.2010.07.227

56. Mayrovitz HN, Sims N. Effects of different cyclic pressurization and relief patterns on heel skin blood perfusion. Adv Skin Wound Care. 2002;15(4):158-64. [PMID:12151981] http://dx.doi.org/10.1097/00129334-200207000-00006

57. Bliss MR. Hyperaemia. J Tissue Viability. 1998;8(4):4-13. [PMID:10480965]

58. Gélis A, Fattal C, Dupeyron A, Pérez-Martin A, Colin D, Pelissier J. Reproducibility of transcutaneous oxygen pressure measurements in persons with spinal cord injury. Arch Phys Med Rehabil. 2009;90(3):507-11. [PMID:19254619] http://dx.doi.org/10.1016/j.apmr.2008.09.564

59. Bergstrom N. The Braden Scale for Predicting Pressure Sore Risk: reflections on the perioperative period. J Wound Ostomy Continence Nurs. 2005;32(2):79-80.

[PMID:15867694]

http://dx.doi.org/10.1097/00152192-200503000-00001

60. Steeves JD, Lammertse D, Curt A, Fawcett JW, Tuszynski MH, Ditunno JF, Ellaway PH, Fehlings MG, Guest JD, Kleitman N, Bartlett PF, Blight AR, Dietz V, Dobkin BH, Grossman R, Short D, Nakamura M, Coleman WP, Gaviria M, Privat A; International Campaign for Cures of Spinal Cord Injury Paralysis. Guidelines for the conduct of clinical trials for spinal cord injury (SCI) as developed by the ICCP panel: clinical trial outcome measures. Spinal Cord. 2007;45(3):206-21. [PMID:17179972] http://dx.doi.org/10.1038/sj.sc.3102008

61. Ross RM, Jackson AS. Exercice concepts, calculations, and computer applications. Indianapolis (IN): Benchmark Press; 1990.

62. Durstine JL, Moore G, Painter P, Roberts S. ACSM's exercise management for persons with chronic diseases and disabilities. 3rd ed. Champaign (IL): Human Kinetics; 2009. 
63. Crespo-Ruiz B, De la Peña-González A, Pérez-Nombela S, Gil-Agudo A. Mechanical and physiological assessment of pressure ulcer-preventing cushions in a population with spinal cord injury. In: van der Woude LHV, de Groot S, Bijker KE, Dekker R, van Aanholt PCT, Hoekstra F, Hettinga FJ, Janssen TWJ, Houdijk JHP, editors. Rehabilitation: mobility, exercise and sports. Amsterdam (the Netherlands): IOS Press; 2009. p. 36-38.

64. Galle N, Vesselle B, Bilesimo M, Etienne JC. [Prevención de las complicaciones del decúbito]. In: Simonnet J. Encyclopédie Médico-Chirurgicale: Kinesiterapia: Medicina física. 26-520-A, 10th ed. Paris (France): Elsevier Science; 2000. p. 1-14. Spanish.

65. Haisma JA, van der Woude LH, Stam HJ, Bergen MP, Sluis TA, Bussmann JB. Physical capacity in wheelchair-dependent persons with a spinal cord injury: a critical review of the literature. Spinal Cord. 2006;44(11):642-52. [PMID:16534502] http://dx.doi.org/10.1038/sj.sc.3101915

66. Bauman WA, Spungen AM. Disorders of carbohydrate and lipid metabolism in veterans with paraplegia or quadriplegia: a model of premature aging. Metabolism. 1994;43(6): 749-56. [PMID:8201966] http://dx.doi.org/10.1016/0026-0495(94)90126-0

67. Lavela SL, Weaver FM, Goldstein B, Chen K, Miskevics S, Rajan S, Gater DR Jr. Diabetes mellitus in individuals with spinal cord injury or disorder. J Spinal Cord Med. 2006; 29(4):387-95. [PMID:17044389]

68. Bauman WA, Adkins RH, Spungen AM, Waters RL. The effect of residual neurological deficit on oral glucose tolerance in persons with chronic spinal cord injury. Spinal Cord. 1999;37(11):765-71. [PMID:10578247] http://dx.doi.org/10.1038/sj.sc.3100893

69. Elder CP, Apple DF, Bickel CS, Meyer RA, Dudley GA. Intramuscular fat and glucose tolerance after spinal cord injury-a cross-sectional study. Spinal Cord. 2004;42(12): 711-16. [PMID:15303112] http://dx.doi.org/10.1038/sj.sc.3101652
70. Gorgey AS, Dudley GA. Skeletal muscle atrophy and increased intramuscular fat after incomplete spinal cord injury. Spinal Cord. 2007;45(4):304-9. [PMID:16940987]

71. Crameri RM, Weston AR, Rutkowski S, Middleton JW, Davis GM, Sutton JR. Effects of electrical stimulation leg training during the acute phase of spinal cord injury: a pilot study. Eur J Appl Physiol. 2000;83(4-5):409-15.

[PMID:11138583]

http://dx.doi.org/10.1007/s004210000263

72. Mohr T, Andersen JL, Biering-Sørensen F, Galbo H, Bangsbo J, Wagner A, Kjaer M. Long-term adaptation to electrically induced cycle training in severe spinal cord injured individuals. Spinal Cord. 1997;35(1):1-16.

[PMID:9025213] http://dx.doi.org/10.1038/sj.sc.3100343

73. Mani R, Gorman FW, White JE. Transcutaneous measurements of oxygen tension at edges of leg ulcers: preliminary communication. J R Soc Med. 1986;79(11):650-54. [PMID:3795208]

74. Byrne DW, Salzberg CA. Major risk factors for pressure ulcers in the spinal cord disabled: a literature review. Spinal Cord. 1996;34(5):255-63. [PMID:8963971] http://dx.doi.org/10.1038/sc.1996.46

Submitted for publication May 13, 2011. Accepted in revised form December 14, 2011.

This article and any supplementary material should be cited as follows:

Crespo-Ruiz B, del-Ama AJ, Jiménez-Díaz FJ, Morgan J, de la Peña-González A, Gil-Agudo ÁM. Physical activity and transcutaneous oxygen pressure in men with spinal cord injury. J Rehabil Res Dev. 2012;49(6):913-24. http://dx.doi.org/10.1682/JRRD.2011.05.0087

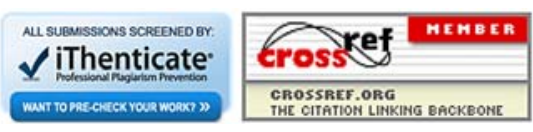

